\title{
SSynthesis
}

International Scientific Conference of IT and Business-Related Research

\section{DIREKTNA STRANA ULAGANJA I NJIHOV ZNAČAJ ZA EKONOMSKI RAST}

\section{FOREIGN DIRECT INVESTMENTS AND THEIR SIGNIFICANCE FOR THE ECONOMIC GROWTH}

\author{
Tatjana Vujić \\ Univerzitet Sinergija Bijeljina, Republika Srpska
}

\begin{abstract}
Apstrakt:
Sa makro stanovišta investicije su determinanta privrednog razvoja u celini, ali i razvoja privrednih subjekata sa mikro stanovišta. Investicije čine nezaobilazan element svake ekonomske politike, jer se njihovom realizacijom ostvaruju pretpostavke, ne samo ekonomskog razvoja, već i stabilnosti privrednih i društvenih tokova. Privlačenje direktnih stranih ulaganja i efikasnost njihovog delovanja predstavlja jedan od najvažnijih ekonomskih zadataka svake vlade. Potražnja za stranim ulaganjima na globalnom tržištu je velika, pa stoga države usmeravaju značajne aktivnosti ka kreiranju što povoljnijeg ambijenta za privlačenje investitora. U radu se posebna pažnja posvećuje direktnim stranim ulaganjima i njihovom značaju za ekonomski razvoj Bosne i Hercegovine, kao i na aktivnosti koje su neophodne kako bi se realizovala povećana ulaganja.
\end{abstract}

\section{Ključne reči:}

direktna strana ulaganja, privredni razvoj, znanja i tehnologije, investicioni ambijent.

\section{UVOD}

Prema klasičnoj definiciji direktne strane investicije (DSI) znače ulaganje u novoosnovano privredno društvo (ustanovu) ili ulaganje u postojeće domaće privredno društvo (ustanovu), koje može biti u stvarima, pravima i novcu. Međunarodni monetarni fond (MMF) definiše direktne investicije kao kategoriju međunarodnih investicija koja odražava pojavu kada rezident koji se nalazi u jednoj zemlji - strani direktni investitor ili matično preduzeće ostvaruje trajne koristi nad preduzećem koje je rezident neke druge zemlje - SDI preduzeće ili preduzeće afilijacija ili inostrana afilijacija. Direktne strane investicije predstavljaju pojavu kada investitor koji se nalazi u jednoj zemlji (zemlja porekla) stiče aktivu u drugoj zemlji (zemlja domaćin) sa namerom da upravlja ovom aktivom. Pri tome pod aktivom se podrazumeva celokupna imovina preduzeća, tj. obuhvata sva sredstva i prava kojima firma raspolaže.

Početkom sedamdesetih godina prošlog veka, ukupna vrednost DSI na globalnom nivou porasla je sa prosečnih 50 milijardi američkih dolara na godišnjem nivou, na 1,9 triliona u 2007. godini. Prema podacima Konferencije Ujedinjenih nacija o trgovini i razvoju (World Investment Report 2014), direktna strana ulaganja u 2013. godini su iznosila 1.45 triliona dolara (1,452 milijarde dolara), što je više za $9 \%$ nego prethodne godine. Nakon smanjenja tokova DSI u 2012. (smanjenje od $22 \%$ u odnosu na 2011.) strane investicije se vraćaju pozitivnom trendu uz procene rasta i u narednim godinama. Prognoze koje su predstavljene u ovom izvještaju govore da će nivo stranih investicija u 2014. godini biti do 1.6 triliona dolara i rasti do 1.7

\section{Abstract:}

From a macro standpoint, investments are the determinants of the overall economic development, as well as the development of economic subjects. Each economic policy is driven by investments, as their implementation provides conditions for the economic development and stability of economic and social flows. The attraction of foreign direct investments and their efficiency is one of the most important economic duties of any government. The demand for foreign investments at the global market is enormous, and thus countries direct significant activities towards creating the most favourable environment and attracting investors. This paper devotes special attention to foreign direct investments and their significance for the overall economic development of Bosnia and Herzegovina, as well as necessary activities for enhanced investments.

\section{Key words:}

foreign direct investments, economic development, knowledge and technology, investment environment.

triliona dolara u 2015, dok se za 2016. godinu procenjuje da će svetske strane investicije dostići 1.8 triliona američkih dolara (UNCTAD, 2014). Veliki značaj za privredni rast svih zemalja, a posebno zemalja u razvoju i zemalja u tranziciji, imaju strana ulaganja, koja su imala značajnu ulogu u strukturnim promenama proizvodnje i izvoza u zemljama korisnicama ovih sredstava. U eri globalizacije važno je razumeti poslovnu logiku iza stranih ulaganja, kao i uticaj koji ta ulaganja imaju na rast bruto društvenog proizvoda, razvoj domaće ekonomije i društva u celini. Osim toga, važno je sagledati greške koje su činile zemlje u razvoju u privlačenju DSI i na osnovu toga izvući pouke o tome kako stvoriti što povoljniji investicioni ambijent u narednom periodu.

\section{EFEKTI DIREKTNIH STRANIH ULAGANJA}

\subsection{ULOGA I ZNAČAJ DIREKTNIH STRANIH INVESTICIJA}

Rastuća uloga i značaj direktnih stranih investicija kao oblika finansiranja svetske ekonomije kontinuirano rastu tokom druge polovine XX veka, a naročito u njegovoj poslednjoj deceniji. Reč je o periodu brojnih reformi u gotovo svim delovima sveta, pad Berlinskog zida i ujedinjenje Nemačke, prestanak hladnog rata, reforme u Kini, raspad Istočnog bloka i pojedinih federalnih država (Sovjetskog Saveza, Čehoslovačke, SFR Jugoslavije), tranzicije ovih i ostalih država iz centralno-planske u tržišnu privredu. Otvaranjem ovih zemalja i otklanjanjem prepreka u kretanju kapitala, otvorile su se mogućnosti za investiranje i intenzivno finansiranje prilivima stranog kapitala širom sveta. 
Savremeni proces globalizacije ima tendenciju brisanja granica tokovima robe, ljudi, kapitala i znanja, čiji su glavni nosioci transnacionalne korporacije (Stakić, 2007, str. 293). Direktne strane investicije predstavljaju deo međunarodnog toka kapitala, koji poslednje dve decenije ostvaruje izuzetan rast. Od početka 90-tih godina, trend rasta DSI beleže i evropske tranzicione države, kada su krenule u proces transformacije svojih privreda. DSI su uticale na porast bruto društvenog proizvoda (BDP-a), generisanje rasta i stimulisanje izvoza ovih privreda. Iskustva tranzicionih zemalja govore da preduzeća koja su u vlasništvu stranog investitora, ostvaruju bolje rezultate nego domaća, imaju dva puta veću produktivnost rada, za $20-30 \%$ veće plate, upotrebljavaju savremenu tehnologiju, zapošljavaju stručniju radnu snagu, više su izvozno orijentisana i ostvaruju veću dobit (Vujić, 2013, str. 77).

Pored visoke tehnologije, direktne strane investicije donose komplementarne prednosti, kao što su znanje i iskustvo u menadžmentu i preduzetničkim sposobnostima. Svojim prisustvom multinacionalne kompanije forsiraju domaća preduzeća na inovacije sa ciljem očuvanja svog tržišnog učešća i profita. Osim toga, one nude poznate marke (brand names) i omogućavaju pristup do regionalnog i svetskog tržišta. Mnogobrojne studije u zemljama u razvoju i zemljama Istočne Evrope pokazale su da usvajanje novih znanja i tehnologija utiče i na postojeće domaće privredne subjekte, koji nova znanja usvajaju kroz saradnju i imitaciju, boreći se za tržište. Nadalje, strane kompanije upućuju zaposlene na različite edukacije izvan zemlje, koji usvojena znanja i veštine koriste u svojoj zemlji. Novi standardi poslovanja koji strane kompanije nameću dobavljačima, špediterima, propagandistima, pa i samim potrošačima, predstavljaju načine na koji nova znanja dođu i do domaćih preduzeća.

Direktna strana ulaganja u nova proizvodna preduzeća ili u proširenje postojećih, najčešće podrazumevaju otvaranje novih radnih mesta, što predstavlja jedno od glavnih prioriteta svake države.

Na priliv direktnih stranih ulaganja se jasno gleda kao na ključni izvor poželjnog priliva stranog kapitala, pa treba imati u vidu da ova mogu odigrati odlučujuću ulogu u transformaciji proizvodne strukture privrede i transferu znanja. One mogu znatno poboljšati izvozne performanse privrede, posebno ako se radi o "vertikalnom" tipu investicija. Dakle, DSI istovremeno teže da "osvoje" domaće tržište ali i da pojačaju izvozne potencijale domaće privrede.

Zbog svih navedenih prednosti koje donose DSI (otvaranje novih radnih mesta, rast plata, dolazak novog kapitala, porast izvoza, nove tehnologije, sveukupno povećanje produktivnosti) vlade zemalja širom sveta osnivaju agencije za privlačenje investicija i strana ulaganja. Kao najvažniji faktori kod odluka o investiranju ističu se: politička i makroekonomska stabilnost, veličina tržišta, ekonomska otvorenost, garancije vlasničkih prava, kvalifikovana radna snaga, infrastruktura, poreska i finansijska politika, te efikasnost javne administracije.

\subsection{DIREKTNA STRANA ULAGANJA I REGULATORNI OKVIR}

Svetska banka svake godine kreira publikaciju pod nazivom Doing Business Report u kome prikazuje uslove poslovanja u 189 zemalja sveta sa pregledom regulatornog okvira. Prilikom izrade ovog izveštaja koriste se empirijska istraživanja o regulatornom okviru iz oblasti osnivanja i likvidacije preduzeća, registracije vlasništva, dobijanja kredita, poštivanja ugovora, tržišta rada. Svakako da će skupe i dugačke procedure za započinjanje i prestanak biznisa odvratiti potencijalne ulagače od dolaska u takvu zemlju. Restriktivni zakoni iz oblasti radnih odnosa uzro- kuju slabiji protok radne snage, što vodi slabijoj razmeni znanja i novih tehnologija. Strani investitori će izbegavati one države za koje smatraju da imaju neefikasan pravosudni sistem, jer im takve neće omogućiti zaštitu uloga.

Bosna i Hercegovina je po Izveštaju Doing Business (2015) po celokupnoj lakoći poslovanja pala sa 104 . na 107 . mesto. Rangiranje po pojedinim indikatorima nije se znatnije promenilo u odnosu na prethodnu godinu, osim dobijanja kredita (skok sa 45. na 36. mesto) i registracija vlasništva (sa 89. na 88. mesto). $\mathrm{BiH}$ je rangirana bolje u odnosu na prosek zemalja Evrope i Centralne Azije u oblastima rešavanja stečaja (34. mesto) i dobijanja kredita (36. mesto). Oblasti na koje treba posebno obratiti pažnju su električna energija - 163. mesto, pribavljanje građevinskih dozvola - 182. mesto, plaćanje poreza - 151. mesto i započinjanje posla - 147. mesto (Tabela 1).

\begin{tabular}{|l|c|c|}
\hline INDIKATORI & $\begin{array}{c}\text { RANG } \\
\mathbf{2 0 1 5}\end{array}$ & $\begin{array}{c}\text { RANG } \\
\mathbf{2 0 1 4}\end{array}$ \\
\hline Započinjanje posla & 147 & 142 \\
\hline Izdavanje građevinske dozvole & 182 & 180 \\
\hline Električna energija & 163 & 160 \\
\hline Registracija vlasništva & 88 & 89 \\
\hline Dobijanje kredita & 36 & 45 \\
\hline Plaćanje poreza & 151 & 142 \\
\hline Međunarodna trgovina & 104 & 103 \\
\hline Poštivanje ugovora & 95 & 95 \\
\hline Rešavanje stečaja & 34 & 32 \\
\hline UKUPNA LAKOĆA POSLOVANJA & 107 & 104 \\
\hline
\end{tabular}

Tabela 1. Indikatori lakoće poslovanja u Bosni i Hercegovini prema izveštaju Doing Business 2015

Po sveukupnoj lakoći poslovanja, od ostalih zemalja jugoistočne Evrope BJR Makedonija je najbolje rangirana (30.mesto), slede Crna Gora (36), Bugarska (38), Rumunija (48), Hrvatska (65), Albanija (68), Kosovo (75) i Srbija (91).

$\mathrm{Na}$ listi prvih 10 zemalja sa najpovoljnim regulatornim okruženjem za poslovanje vodeći je Singapur, zatim slede Novi Zeland, Hong Kong, SAR, Kina, Danska, Republika Koreja, Norveška, Sjedinjene Američke Države, Ujedinjeno Kraljevstvo, Finska i Australija.

Na tabeli konkurentnosti u Izveštaju Svetskog ekonomskog foruma o konkurentnosti 2014-2015 (WEF) nalaze se 144 zemlje, među kojima nema Bosne i Hercegovine (World Economic Forum, 2015).

Pomenuta godišnja publikacija Svetske banke, kao i WEF Izveštaj o kokurentnosti ukazuju da je pred $\mathrm{BiH}$ dug put privrednih reformi na stvaranju povoljnog privrednog ambijenta, kojima će privući strana ulaganja.

\subsection{STANJE DIREKTNIH STRANIH ULAGANJA U BOSNI I HERCEGOVINI}

Bosna i Hercegovina je 16. juna 2008. godine potpisala Sporazum o stabilizaciji i pridruživanju sa Evropskom unijom i time postala potencijalni kandidat za članstvo u ovoj ekonomskoj integraciji. Na taj način su Bosni i Hercegovini otvorena nova vrata kada su u pitanju i direktne investicije i saradnja sa regionom.

Prema zvaničnim podacima Centralne banke $\mathrm{BiH}$ iz avgusta 2014. godine, ukupna direktna strana ulaganja u $\mathrm{BiH}$, na kraju 2013. godine su iznosila 11,044 miliona KM ili 11 milijardi 
KM (5,647 miliona evra ili 5.6 milijardi evra). Strane direktne investicije u 2013. godini su iznosile 418 miliona KM ili 214 miliona evra (Agencija za unapređenje stranih investicija u Bosni i Hercegovini, 2014). Tokovi direktnih stranih ulaganja u Bosni i Hercegovini u periodu od 2006. godine do oktobra 2014. godine prikazani su slikom 1 .

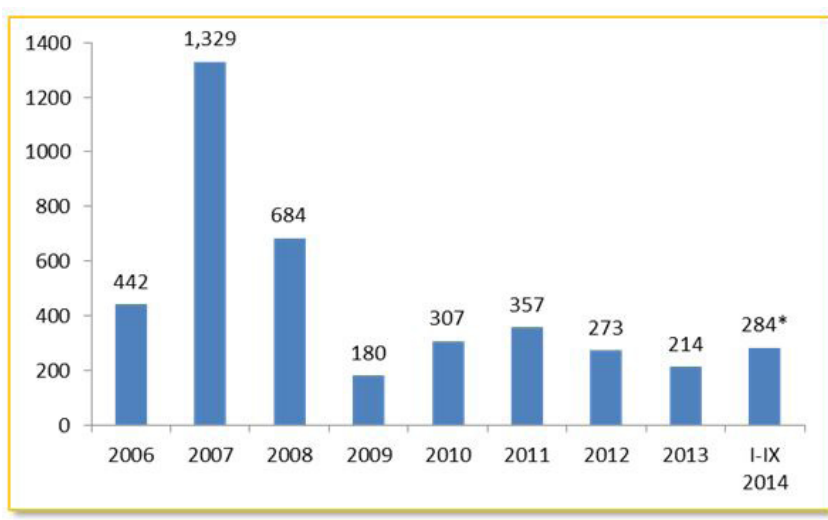

Slika 1. Tokovi direktnih stranih ulaganja u $\mathrm{BiH}$ po godinama (milioni evra)

Izvor: Centralna Banka $\mathrm{BiH},{ }^{*}$ privremeni podatak bez reinvestiranih zarada

Bosna i Hercegovina je, zahvaljujući privatizaciji velikih državnih preduzeća u 2007. godini imala priliv DSI od $1.3 \mathrm{mi}-$ lijarde evra, što je najveći godišnji iznos ostvaren u poslednjih devetnaest godina. Već naredne godine priliv DSI od $684 \mathrm{mi}-$ liona evra, bez očekivane privatizacije, može se smatrati zadovoljavajućim, naročito ako se uzme u obzir njegova pozitivna struktura (ulaganje u proizvodni sektor i visoko učešće „greenfield“ ulaganja). U narednom periodu, uticaj svetske ekonomske krize odrazio se na priliv DSI. Priliv DSI u 2010. godini iznosio je 307 miliona evra. Revidirani podaci za 2011. i 2012. godinu, pokazuju porast investicija u 2011. u odnosu na 2010. godinu od $16.3 \%$, dok je u 2012. godini ostvaren pad investicija u odnosu na 2011. godinu od 23.5\%. Pored najavljenih projekata stranih investora, kao i obećavajućih procena, DSI u 2013. godini su iznosila 214 miliona evra, što predstavlja smanjenje od 21,6\% u odnosu na prethodnu godinu. Podaci o prilivu DSI za period januar - septembar 2014. godine su privremeni, ne uključuju reinvestirane zarade i iznose 284 miliona EUR.

Ukupno stanje direktnih stranih ulaganja na kraju 2013. iznosilo je 5.6 milijardi evra ili 11 milijardi KM, a najveći iznos se i dalje odnosi na Austriju (2.6 milijardi KM ili 1.3 milijarde evra), Srbiju (2 milijarde KM ili 1 milijardu evra) i Hrvatsku (1.4 milijarde KM ili 733 miliona evra). Najznačajnije zemlje investitori u $\mathrm{BiH}$ prikazane su Slikom 2:

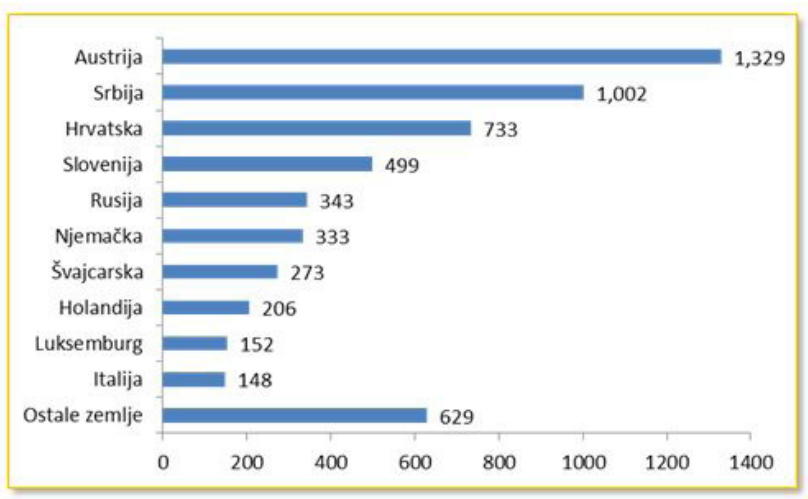

Slika 2. Najznačajnije zemlje investitori u $\mathrm{BiH}$ u periodu maj 1994 - decembar 2013. (milijarde evra)
Zemlja koja je najviše investirala u 2013. godini je Srbija (62 miliona KM), zatim slede Velika Britanija (56 miliona KM), Austrija (51 milion KM), Švajcarska (44 miliona KM) i Nemačka (40 miliona KM).

Posmatrano po sektorima ulaganja u periodu od maja 1994. do decembra 2013. godine, najznačajniji iznos DSI je investiran u sektor proizvodnje (32\%). Značajno učešće u okviru ukupnog priliva direktnih stranih ulaganja imao je i bankarski sektor $(22 \%)$. Slede ulaganja u telekomunikacije (15\%) i trgovinu (11\%). Stanje direktnih stranih ulaganja po sektorima prikazano je slikom 3 :

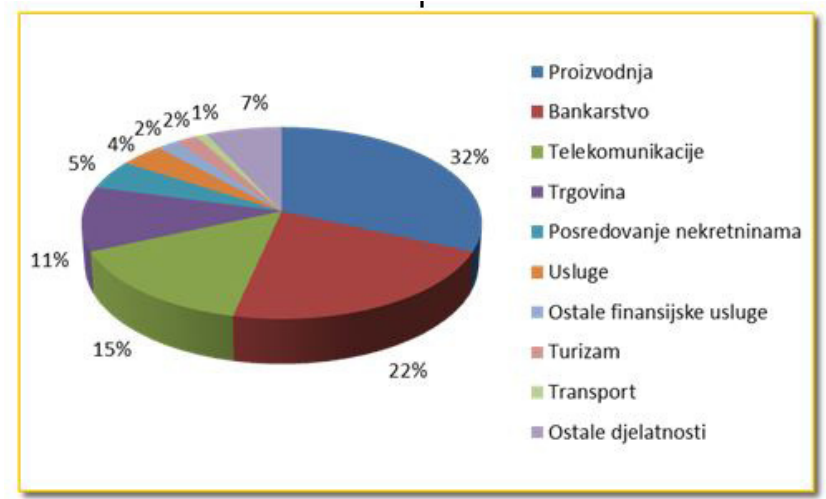

Slika 3. Direktna strana ulaganja u $\mathrm{BiH}$ po sektorima u periodu maj 1994 - decembar 2013.

U 2013. godini najznačajnije učešće stranih investicija je registrovano u sektoru bankarstva (34\%), zatim slede sektori: posredovanje nekretninama (9\%), usluge (9\%), proizvodnja (8\%), trgovina (6\%), turizam (4\%) i telekomunikacije (4\%).

\section{DOBAR INVESTICIONI AMBIJENT}

Gotovo da ne postoji država u svetu koja stvaranjem povoljnog investicionog ambijenta ne želi da privuče direktna strana ulaganja. Putem publikacija kao što je "Bela knjiga" gotovo sve zemlje regiona ukazuju na potrebne reforme, kao bi se unapredio investicioni ambijent. Pomenuta publikacija Svetske banke "Doing Business" takođe pruža informacije o pogodnosti za investiciona ulaganja, kao i sektore u kojima je potrebno izvršiti reforme.

Želje investitora su da ostvare što veću stopu prinosa, a da istovremeno izbegnu rizik (Vukadinović \& Jović, 2012, str. 195). Istraživanja pokazuju da se kao najvažniji faktori kod donošenja odluka o ulaganjima ističu: politička i makroekonomska stabilnost, veličina tržišta, zagarantovanost vlasničkih prava, ekonomska otvorenost, transportna infrastruktura, te kvalifikovana radna snaga. Svakako da ne treba zanamariti ni efikasnost javne administracije, poresku politiku i finansijske stimulanse.

U skladu sa Zakonom o politici direktnih stranih ulaganja u Bosni i Hercegovini (Službeni glasnik BiH, br. 17/98, 13/03, 48/10) stranim investitorima garantovano je sledeće:

- Nacionalni tretman stranim ulagačima, podrazumeva da strani ulagači imaju ista prava i obaveze kao i rezidenti Bosne i Hercegovine.

- Strani ulagači imaju pravo, radi svojih ulaganja, na teritoriji Bosne i Hercegovine da otvore račune kod bilo koje poslovne banke u domaćoj ili slobodnoj konvertibilnoj valuti. 
- Strani ulagači će imati pravo na slobodno zapošljavanje stranih državljana iz inostranstva ukoliko nije određeno drugačije zakonima u Bosni i Hercegovini o radu i useljavanju.

- Strani ulagači su zaštićeni od nacionalizacije, eksproprijacije, rekvizicije i mera sa jednakim učinkom; takve mere mogu se preduzeti isključivo u javnom interesu, $\mathrm{u}$ skladu sa važećim zakonima i podzakonskim aktima, uz plaćanja primerene naknade.

- Strani ulagači imaju ista vlasnička prava nad nekretninama kao domaći pravni subjekti.

- Strani ulagači imaju pravo obavljanja transfera u inostranstvo, slobodno i bez odlaganja, u slobodnoj konvertibilnoj valuti, dobiti koja nastane kao rezultat njihovog ulaganja u Bosni i Hercegovini.

Strana ulaganja u BiH izuzeta su od plaćanja carina i carinskih obaveza, osim putničkih vozila, automata za zabavu i za igre na sreću. Republika Srpska, Federacija BiH, kao i Brčko Distrikt zakonima su regulisali poreska oslobađanja za strane ulagače. Strani investitori u Bosni i Hercegovini imaju mogućnost obezbeđenja od političkih rizika (restrikcija transfera, eksproprijacije, ratnih i civilnih nemira, uskraćivanja pravosuđa) uz pomoć Fonda Evropske unije za garantovanje investicija, kojim upravlja MIGA (Multilateralna agencija za garantovanje investicija, članica Svetske bankarske grupe). Pri tome, MIGA daje garancije, tehničku pomoć i pravne usluge, a pored zaštite od političkog rizika, njen značaj je i u pružanju suosiguranja i reosiguranja od rizika. $\mathrm{BiH}$ je takođe i članica Skupštine evropskih regija, što može uliti dodatnu političku sigurnost investitorima.

I pored toga, reformski zahvati moraju da se nastave i obuhvate i ostale oblasti u kojima Bosna i Hercegovina zaostaje za zemljama okruženja, čija reforma je mnogo brža i efikasnija, kako bi se kreirala još bolja slika atraktivne lokacije za investiranje. Vladavina prava i zaštita privatne svojine jedan od osnovnih zadataka u tom pravcu.

Pred kreatorima ekonomske politike stoji ozbiljan zadatak na rešavanju pitanja za dalji razvoj kao što su smanjenje administrativnih prepreka, izgradnja infrastrukture, reforma obrazovnog sistema u skladu sa potrebama privrede, uklanjanje postojećih monopola na tržištu.

\section{ZAKLJUČAK}

Uloga i značaj stranih ulaganja na ekonomski rast zemlje ne može biti prenaglašen i upitan. Čak i jake i stabilne ekonomije sveta kreiraju politiku koja će im obezbediti povoljnu investicionu klimu. Privlačenje direktnih stranih investicija, predstavlja osnovni uslov za povećanje proizvodnje i izvoza zemalja domaćina do nivoa koji bi joj omogućio stabilan ekonomski rast, kao i uspešno servisiranje dugova, te je stoga jedan od osnovnih ciljeva kreatora ekonomske politike upravo stvaranje investicione klime koja pogoduje privlačenju stranih ulagača. Priliv sredstava putem direktnih stranih investicija predstavlja ne samo priliv kapitala, već osnove za povećanje trgovinskih tokova, ekonomskog rasta i razvoja i kreiranje novih radnih mesta. Bosni i Hercegovini kao zemlji u tranziciji, neophodne su strane direktne investicije koje bi činile glavni pokretač ekonomskog rasta zemlje u narednom periodu. S obzirom na nizak nivo domaće štednje iz koje bi se samostalno finansirao razvoj, nedostatak savremene tehnologije, kao i odgovarajućeg upravljačkog znanja, pomenuti nedostaci mogu se nadoknaditi dolaskom stranih investitora, koji bi doneli nova znanja, iskustva i tehnološki napredak. Upravo stoga, privlačenje stranih investitora i prilagođavanje njihovim zahtevima kroz ubrzan proces reformi, jedan je od ključnih zadataka koji stoji pred BiH i njenim entitetima.

\section{LITERATURA}

Agencija za unapređenje stranih investicija u Bosni i Hercegovini. (2014). Direktna strana ulaganja: stanje i performance. Preuzeto 13. januara 2015. sa http://www.fipa.gov.ba/informacije/statistike/investicije/default.aspx?id=180\&langTag=bs-BA

Doing Business. (2015). Doing Business 2015: Going Beyond Efficiency. Preuzeto 13. januara 2015. sa http://www.doingbusiness.org/reports/global-reports/doing-business-2015

Službeni glasnik BiH. (2010). Zakon o politici direktnih stranih ulaganja u Bosni i Hercegovini. Službeni glasnik BiH, br. 17/98, 13/03, 48/10. Preuzeto 13. januara 2015. sa http://fipa.gov.ba/publikacije_materijali/zakoni/default.aspx?id=315\&langTag=en-US

Stakić, B. (2007). Finansijski i devizni menadžment u turizmu. Beograd: Univerzitet Singidunum.

UNCTAD. (2014). World Investment Report 2014. Preuzeto 13. januara 2015. sa http://unctad.org/en/PublicationsLibrary/ wir2014_en.pdf

Vujić, T. (2013). Spoljnotrgovinsko i devizno poslovanje Bosne i Hecegovine. Bijeljina: Univerzitet Sinergija.

Vukadinović, P., \& Jović, Z. (2012). Investicije. Beograd: Univerzitet Singidunum.

World Economic Forum. (2015). The Global Competitiveness Report 2014 - 2015. Preuzeto 13. januara 2015. sa http:// www.weforum.org/reports/global-competitiveness-report-2014-2015 